\title{
Training and Promotion of Humanities Cultivation for Engineering Students
}

\author{
Xuemei Bai \\ School of Electronic and Information Engineering \\ Changchun University of Science and Technology \\ Changchun, China \\ xmbai@cust.edu.cn
}

\author{
Feng Wang \\ School of Electronic and Information Engineering \\ Changchun University of Science and Technology \\ Changchun, China \\ 770736667@qq.com
}

\begin{abstract}
Nowadays, many university students pay more attention to the high-salary job and pay less attention to the multi-aspect development and excellent personal qualities. They are affected by the atmosphere of society fickleness and the cognition of many people of paying much attention to the economic benefits. In a specific situation, students only focus on their scores, rankings and other related qualities, rather than their professional interest and enthusiasm. Therefore, many engineering students are general blundering and perplexed when they are asked what they want to do or their favorite jobs. And more seriously, engineering students in technological university haven't been aware of the significance to increase themselves humanities cultivation. Humanistic quality plays a decisive role in university students' life about their later work and daily life. Humanistic knowledge is seriously rare for present engineering students and as a result, the work to improve humanistic education is becoming more necessary than before. One reason is that earning humanistic knowledge has fewer requirements in technological university and the other reason is that social leading is lack of guidance and requirements for humanities cultivation. In general, humanities cultivation takes up an important position in all aspects of the development of engineering students.
\end{abstract}

Keywords- humanities cultivation; educational reform; technological training; humanistic quality; teaching pattern

\section{HUMANITIES AND HUMANITIES CULTIVATION}

Humanistic spirit is an important yardstick to measure a human being's humanistic quality. And this quality is formed through continuous autonomous learning and cognition. It is a long-term project. As one's ability, knowledge, belief, emotion, action always are in the motivation of changing, its connotation doesn't equal to extension (W. Liu. 2011). There are three important elements about humanistic qualities: humanistic knowledge, humanistic spirit and humanistic practical ability. We can know that humanistic knowledge is the foundation of students, promoting humanistic spirit continually is kernel and better efficient humanistic practical capacity is the ultimate aim. How to develop humanistic quality and culture quality is closely related to teachers' guidance and the surrounding living environment.

\section{A. Humanistic knowledge}

Humanistic knowledge can be treated as the general achievement and summary through the process that people transform themselves and understand the society. Different to the natural science knowledge, humanistic quality education is to impart humanities and social science knowledge. Due to long-term classification between liberal arts and science, engineering students are in such a condition that less sufficient knowledge of humanities to enhance self-cultivation (Q.T.Wang \& L.J.Zhou. 2011). Sufficient knowledge of humanities is an essential element to shape the students' correct outlook of the world, life and values. It can improve students' spirit of bearing hardships and set up lofty professional ethics, cultivate the students' ability about feeling and appreciation ability of beauty, broaden the students' thought and enrich students' imagination.

\section{B. Humanities spirit}

Humanities spirit contains both historical and age character. This spirit has been given various meanings in different ages. Only realizing the historic character of humanism, can students totally comprehend the connotation of humanistic spirit, absorb the essence of traditional humanistic spirit, increase their cultural awareness and raise their humanistic spirit simultaneously through combining with ages' character of humanities (G.Y.Zhang. 2011).

With the development of society, material wealth enriches citizens greatly. Accordingly, it also changes the course peoples' moral consciousness and value orientation away from that of before. Therefore, it is necessary to guide students to set up the correct world outlook and life outlook so that they can use developing eyes to evaluate their own value for survival.

\section{Humanistic practical ability}

Humanities practice ability is the manifestation of literature quality and is the way that people deal with things around themselves and get along with others. The main expression form of humanistic practical ability is the way for people how to treat oneself. In the meantime, it requires people to have strict self-discipline and selfregulation ability to constantly improve their knowledge training and practice ability (X.L.Dong. 2013). From the observation, we can summarize one's level of humanistic quality with the judgment and conclusion of one's cultural quality. 


\section{OVER VIEW OF THE HUMANITIES EDUCATION FOR THE ENGINEERING STUDENTS IN CHINA}

\section{A. Humanities education situation of the students in engineering university}

At present, there is only few opportunities and little time for the students to be aware of the importance of the humanities knowledge and Chinese excellent traditional culture inside of the universities, besides some extracurricular activities in their spare time and most opportunities and time are devoted to the science and engineering (L.Huang. 2009). The contents of getting humanities are from books and are a simple recitation. In the meanwhile, most students of science and engineering are lack of the awareness of the humanities, due to the traditional thought that only the "science-education" can cultivate the talents and they regard the humanities as the useless. They have better logical thinking, but worse visualized thinking. This will cause a big issue that graduation students will face a host of problems, such as poor expression, poor handwriting and etc. when they go to work.

The university procedure is a key stage for students' free development. But misleading of thoughts is very dangerous and it is a challenge for students to solve the problems one by one. They will take their major courses as "technology courses". On the other hand, the social problems will affect badly on the thought of students and distort their souls. And it is not benefit to their personality cultivation. Under the big surrounding, many students are short of love heart and responsibility. Therefore, more utilitarian education rather than the humanistic education adds on the students.

The students are influenced by the tradition in China and aim at successes in the university entrance exam for their ideal university. They are lack of the knowledge of humanity, which leads to a mistake that only thing they care about is to master necessary professional knowledge and regard the humanities as a burden.

Most students take the humanities quality courses inexpressive. Firstly, they regard the courses as monotonous and boring. Then, those courses can't bring real-life profit to their life. That is said, as the students think, humanistic quality education is far away from their real life. So, the students can't deal with the humanities correctly under the negative attitudes and they avoid the humanities course deliberately or refuse accepting this type knowledge. Maybe they are willing to do other things, such as surf the internet and play the computer games. In a word," Don't let me learn humanities".

Faced with the big pressure from lots of competitions, students must grasp much professional knowledge and they are necessary to approve their ability of practice simultaneously. Students don't have enough time to learn the humanities and the professional knowledge study will even take up the time of the humanities. Students will drop up learning on humanities knowledge under contrasting the two conditions. In their opinion, the shortage of the humanities in a short time can't bring some bad effect on them.

\section{B. The reason for the literary accomplishment lack}

The trend of the higher education development is that science and engineering will combine with humanities and the structure of higher education must adapt to the demands of the development of science and technology. In the 1950s, university departments' adjustment caused the separation of liberal arts and science, but the thought of utilitarianism about education deemed that the highly centralized planning and unified education system are the biggest resistance against education reform. With the deepening of the reform of colleges and universities, people understand deeper and deeper the importance of the humanities development in science and engineering universities. It can not only improve students' cultural quality, but also cultivate the talents of having both ability and political integrity.

Along with the rapid development of science and technology, human society productivity level is increasing day by day and the world economy achieved unprecedented prosperity. However, science and technology is not only accelerating the process of human social development, but also increasing some negative effects obviously, such as the excessive exploitation of energy, unethical application of biological technology and a large number of environmental pollution. The nature of the environment pollution and energy crisis, at the same time also leads to the ethics of landslides. People gradually realize the disadvantages of the one-sided emphasis on the development of science and technology and constantly think and seek the way to solve the problem and pay more attention to the guidance role of the humanities (M.Hu. 2007). Therefore, humanity is a key link in the process of talent training.

\section{THE SIGNIFICANCE OF DEVELOPING HUMANISTIC QUALITY EDUCATION}

\section{A. Cultivating students with high humanistic quality}

The humanistic quality of the ascension is a necessary condition to improve the innovation ability of university students and the basic premise. The humanistic quality is also the quality that the innovative talents must possess. For a long time, it was to cultivate talents, but not to create talents in China and it largely hindered the science and technology innovation. The main reason is to strengthen excessively the professional education especially in engineering university, pay attention to scientific knowledge and professional skills training and neglect the improvement of students' humanistic quality. Most people think that reducing the humanistic quality education will make a quick success and instant benefit in teaching. Hedy LaMarr, the mother of FM technology obtained achievements in the field of CDMA after she had starred in a film called 'be dazzle' by the Czechoslovakia film company. A great part of the reasons why she concentrated on radio communication is that she wanted to prove that she was not a vase, which means her humanities reached a certain level and it's a reflect for her pursuing higher life ideal.

It is the most important for the modern higher education to cultivate talents with strong practical ability and good comprehensive quality in relevant scientific knowledge. Talents are the rejuvenation of the country. 
Talents with both ability and political integrity are the precious resources of China to continue to develop and expand in the process of economic globalization.

\section{B. Cultivating students with all-round development}

China's education reform is to convert exam-oriented education to quality education and this shift needs a process of adaptation. One consequence of examinationoriented education is a serious side branches and the engineering university students often need to write topic reports. However, a number of university students could not even write out smoothly and the situation will bring a great influence to their later work and also no more to talk about technological innovation.

At present, dictation teaching is still the main way of university education in China. Most of the teachers are talents of the traditional education, which leads them only to teach students "what this is", but not inspire the student to think about "why". It only lets the students accept knowledge passively, but students can't take the initiative to find and solve problems and the student's enthusiasm, initiative and participation are neglected. But humanities class teaches it vividly and concretely and it also combine the scientific quality with the students' logical thinking and pay more attention to the adaptation of the students to think about the "why".

\section{MEASURES FOT THE IMPLEMENTATION OF HUMANISTIC QUALITY EDUCATION}

\section{A. Students-centered mode}

People-oriented is the important guidance theory of students' humanity quality education, which guides the direction of the humanistic quality cultivation. As the theory said, education should adhere to student-centered and education should respect students' personality and difference, realize significance of students' personalized development and strive to provide the best platform and opportunity for students to growth and development. Under this environment, it can broaden the students' view on knowledge, cultivate students' good character and then create a good atmosphere for students to have a healthy growth and all-round development. As a result, curriculum design should respect the students' interests, the system of the campus construction should fully embody, conform to and pay attention to the humanistic principle, and the cultivation of the humanities can't be ignored.

\section{B. Teaching pattern's transformation}

Humanities-type courses are few in the universities of science and engineering, so this requests teachers to improve students' humane quality within the limited class hours. Teaching mode should be reformed to change the situation that humanities accomplishment courses aren't accepted and loved by students. Teachers from different subjects should reorganize their own subjects. Take the course nearly all students learned as an example. Students have learned history since they were in junior schools and they have known almost the knowledge in the book. If teachers talk about the historical development again in undergraduates' courses, they ought to feel boring, baldness and even produce the mood of students' studyweariness. Teachers might as well change a point of view and teach the nature reasons hiding in every historical reasons and what profit promoted this historical changes. It will be full of confidence to attract the students' attention and cultivate their ability to think deeply through teaching from different point of views. Humanistic accomplishment is also to be improved further. Under the premise that the great importance are attached to strengthen the natural science foundation, the current emphases should be the engineering and practical competency, communication ability, team cooperation spirit, lifelong learning ability, professional ethics, social responsibility, social humanities and economic management.

\section{Suitable environments' creation}

The influence about environment is subtle and profound for persons. Many scholars have made rational interpretation about the momentous role of university campus cultural environment, which plays an important role to guide students' personality. Therefore, a favorable campus environment has edification effect on university students' humanistic quality. As is said by the famous "pickle theory" from Professor Xuyou Guang of Huazhong University of Science and Technology, the taste of the pickled vegetable is decided by the pickle water not the vegetable itself. As the excellent campus environment is the good pickle water and the students can be 'pickled' in the scientific thinking methods and behavior style. The students can be cultivated to advanced professional talents with integrated personality and proficient ability under an excellent ecological environment of campus. So building a health and active campus environment is conducive to the development of students, which is indispensable. The most important, teachers and school leaders need to lead as a good example and increase the propaganda about culture learning's importance. Only all the educators pursue the humanistic spirit with persistence, can drive the whole school's cultural atmosphere and even around it. Moreover, more various cultural activities should be held to improve students' humanities accomplishment. Rich and colorful communities and student union's activities also can be used to improve culture accomplishment.

\section{CONCLUSIONS}

The rapid progress of society needs all-round development talents. It is the duty of education to cultivate creative talents who can meet the requirements of social development in the new era. The educators should be clear to understand what the education lack is of and what the educators should be supposed to do. At present, students in the science and engineering are commonly absent of the humanities and the humanities education must be strengthened. Abundant university students' life, positive leading practice and reforming the existing teaching modes can reinforce the humane abilities of students.

The paper mainly analyzes the definition, affection and significance of the humanities and makes it clear that the development directions and difficulties faced by the educators. There are some issues to be solved and discussed further due to writers' general ability and limited proficiency.

\section{REFERENCES}

[1] G. Eason, B. Noble, and I. N. Sneddon, "On certain integrals of Lipschitz-Hankel type involving products of Bessel functions," 
Phil. Trans. Roy. Soc. London, vol. A247, pp. 529-551, April 1955. (references)

[2] J. Clerk Maxwell, A Treatise on Electricity and Magnetism, 3rd ed., vol. 2. Oxford: Clarendon, 1892, pp.68-73.

[3] I. S. Jacobs and C. P. Bean, "Fine particles, thin films and exchange anisotropy," in Magnetism, vol. III, G. T. Rado and H. Suhl, Eds. New York: Academic, 1963, pp. 271-350.

[4] K. Elissa, "Title of paper if known," unpublished.

[5] R. Nicole, "Title of paper with only first word capitalized," J. Name Stand. Abbrev., in press.

[6] Y. Yorozu, M. Hirano, K. Oka, and Y. Tagawa, "Electron spectroscopy studies on magneto-optical media and plastic substrate interface,” IEEE Transl. J. Magn. Japan, vol. 2, pp. 740-
741, August 1987 [Digests 9th Annual Conf. Magnetics Japan, p. 301, 1982].

[7] M. Young, The Technical Writer's Handbook. Mill Valley, CA: University Science, 1989.

[8] Electronic Publication: Digital Object Identifiers (DOIs):

[9] D. Kornack and P. Rakic, "Cell Proliferation without Neurogenesis in Adult Primate Neocortex," Science, vol. 294, Dec. 2001, pp. 2127-2130, doi:10.1126/science.1065467.

[10] H. Goto, Y. Hasegawa, and M. Tanaka, "Efficient Scheduling Focusing on the Duality of MPL Representatives," Proc. IEEE Symp. Computational Intelligence in Scheduling (SCIS 07), IEEE Press, Dec. 2007, pp. 57-64, doi:10.1109/SCIS.2007.357670. 